\title{
Analysis of the Mechanization Index of Wheel Tractors in Rural Farm Holdings
}

\author{
Anderson Chagas Magalhães ${ }^{1}$, Johnny Maciel de Souza ${ }^{2}$, Murilo Antonini Santana ${ }^{2}$ \& Omar Jorge Sabbag ${ }^{3}$ \\ ${ }^{1}$ Agronomy Engineering Course, UNESP-Univ Estadual Paulista, Dracena, Brazil \\ ${ }^{2}$ Animal Science Course, UNESP-Univ Estadual Paulista, Dracena, Brazil \\ ${ }^{3}$ Ilha Solteira Engineering Faculty, UNESP-Univ Estadual Paulista, Ilha Solteira, Brazil \\ Correspondence: Anderson Chagas Magalhães, UNESP-Univ Estadual Paulista, Campus of Dracena, Agronomy \\ Engineering Course, Comte João Ribeiro de Barros Road, km 651, 17900-000, Dracena, SP, Brazil. Tel: \\ 55-18-3821-8200. E-mail: amchagas@dracena.unesp.br
}

Received: July 30, 2013 Accepted: September 5, 2013 Online Published: October 15, 2013

doi:10.5539/jas.v5n11p127 URL: http://dx.doi.org/10.5539/jas.v5n11p127

\begin{abstract}
The Brazilian agriculture presents different production systems and a great variation of yield levels as a consequence of the regional inequality. These variations occur mainly because of the lack of technical information and financial support to acquire machinery and equipment used in agriculture. Considering the importance of this information, this study aimed to analyze the mechanization of agricultural properties in the municipality of Dracena/SP. The total number of land holdings in this area is 1,024 and only 149 have wheel tractors; they were classified into groups according to their sizes. Data collection was done through a questionnaire about the characteristics of the production system, mechanization resources, operational cost, and operational intensity. The statistical significance of the experimental data was evaluated by analyses of variance followed by Kruskal Wallis' test $(\mathrm{P}<0.05)$. The analysis revealed that the average values of the mechanization index and the farmed area by tractor were, respectively, $2.53 \mathrm{~kW} / \mathrm{ha}$ and $103.9 \mathrm{ha} /$ tractor. The analysis further revealed that the field operational cost was minimized with the maximization of the effective operational capacity for any area group.
\end{abstract}

Keywords: field capacity, operational cost, agricultural tractor, mechanization index

\section{Introduction}

The Brazilian agriculture has several production systems and a great variation of yield levels as a consequence of the regional inequality. Thus, highly-technical productive properties coexist with underdeveloped agriculture that is little dynamic and has a strong component of traditional crops. These variations occur mainly due to the lack of technical information, strategic policies and financial support for the acquisition of machinery and equipment (Federação da Agricultura e Pecuária do Estado de Mato Grosso-FAMATO, 2007).

The knowledge on machinery and how this machinery has been adapted to the actual conditions of the cultivated land is extremely important to minimize the producers' loss. Machinery or implements that exceed the needs of a cultivated land or supersized machines that exceed the actual demand, result in increased cost due to their low utilization. Likewise, less machinery or implements that do not meet the operational needs, or undersized machines, can prevent the execution of operations within the available time, resulting in losses of the product quantity and quality. Therefore, proper selection of technology is required related to the farmers' level of knowledge and technical information as well as to their management abilities (Lotte, 2005; Silveira et al., 2006; Gimenez \& Milan, 2007; Ereno, 2008).

The selection of machinery is related to the characteristics of each land holding, and the influencing factors are the mechanization index, cultivated area, capacity and required operation cost, cultivation practices, number of crops under exploration, and climatic conditions. As an example, Andrade and Jenkins (2003) studied the mechanization dynamics of two agricultural farms of Mexico, and determined that it was necessary to make the productive activities more technical using political strategies to increase the mechanization index according to the size of the properties, reducing the technological inequality in the regions, and increasing yield.

According to Vilagra (2009), increasing utilization of agricultural machinery is a consequence of the changes in 
the agricultural demand, substituting manual labor and animal use by machines, modernizing agriculture, and allowing the exploration of larger cultivation areas. The result of increased mechanization of agriculture also favored the development of the industrial and service sectors.

Karimi et al. (2008) utilized the mechanization index to determine the distribution of tractors in the region of Isfahan Province in the central region of Iran. The mechanization index showed how the production in the agricultural sector was directly influenced by the amount of available potential of a tractor. According to the authors, in some regions, the agricultural standards were inadequate to carry out most of the agricultural operations within the available time, and that caused the reduction of the mechanization index because the available tractors were not able to perform all agricultural operations within the limited time. These regions chose to receive new tractors in order to increase their mechanization index. Samavatean et al. (2011) analyzed the energetic efficiency and the economic performance of garlic production in Hamedan, province of Iran, and concluded that the energetic efficiency and the economic development of garlic production improved when the mechanization index increased.

Olaoye and Rotimi (2010) determined the effect of mechanization on agricultural yield in some farms that were established in two states in the southwest of Nigeria. It revealed that old tractors with low mechanization level contributed to low operational yield. Studies showed that the mechanized system of the crop production in both states is economically necessary but with a relatively low cost-benefit relationship, despite of subsidies given to farmers.

Thus, this study aimed to analyze the mechanization index of agricultural farms in the municipality of Dracena, SP, Brazil, to determine the impact of mechanization in the production cost, so that the mechanized operations be carried out efficiently and economically.

\section{Material and Methods}

This study was done in the Campus of UNESP, Dracena/SP, Brazil. The choice of rural properties for the field study was determined with the help of CATI (Coordenadoria de Assistência Técnica Integral-Coordination of Integral Technical Assistance), Regional of Dracena, which allowed the access to the farmers' database in the municipality. This database showed that property stratifications had been done according to the area size.

Direct interviews with farm owners or their managers was done to collect information. The approach process for data collection follows the flow chart by Ereno (2008). The data were tabulated, processed and analyzed, utilizing an electronic spreadsheet, according to Rodrigues et al. (1997).

The mechanization index $\left(\mathrm{I}_{\mathrm{M}}\right)$ was determined by adding the drawbar farm power of the tractor that are utilized in mechanized operations of the total cultivated area according to Ereno (2008).

$$
\text { Mechanization Index }(\mathrm{kW} / \mathrm{ha})=\frac{\sum_{\mathrm{i}=1}^{\mathrm{n}}(\text { Drawbar horse power of the tractors })_{\mathrm{i}}}{\sum_{\mathrm{i}=1}^{\mathrm{n}}(\text { Area farmed by tractors })_{\mathrm{i}}}
$$

The drawbar horse power of the tractors was determined by Equation 2, and estimated as per American Society of Agricultural Engineers-ASAE D497.4, (2003). The brake horse power of the tractor was obtained from the information given in the manufacture's manual.

$$
\mathrm{O}_{\text {dhp }}=0.92 \times\left(\mathrm{O}_{\text {bhp }} \times 0.735497\right)
$$

In which:

$\mathrm{O}_{\text {bhp }}=$ brake horse power of the tractor, hp; and

$\mathrm{O}_{\mathrm{dhp}}=$ drawbar horse power of the tractor, $\mathrm{kW}$.

The effective operational capacity was obtained by adding the useful area farmed by the machine by the real effective time unit (Mialhe, 1996; ASAE D497.2,1999). To determine the effective real time or total time in which the machine was carrying out mechanized operations in the area, the down time, time wasted on maneuvers, adjustments and regulation, plus the working time, the one really spent on area farming, were considered (Silveira et al., 2006). 


$$
\mathrm{C}_{\mathrm{EO}}=\frac{\sum_{\mathrm{i}=1}^{\mathrm{n}} \text { (Areafarmedby machinery) }}{\sum_{\mathrm{i}=1}^{\mathrm{n}} \text { (Total timespenton area by machinery) }}
$$

In which:

$\mathrm{C}_{\mathrm{EO}}=$ effective operational capacity, ha/h. total time spent on area by machinery.

To determine the field operational rhythm, it was necessary to verify all the operations that were performed and the periods for each performance. It was necessary to estimate the available useful time of the period for the machinery work in function of edaphoclimatic conditions and the adopted working period for each operation (Mialhe, 1996). The useful time also depended on the number of days reserved for each operation, and then the inappropriate days, Sundays and holidays that were not worked. Thus, the next equation is given:

$$
\mathrm{T}_{\mathrm{U}}=\left(\mathrm{N}_{\mathrm{O}}-\mathrm{N}_{\mathrm{I}}\right) \times \mathrm{W}_{\mathrm{P}} \times \mathrm{M}_{\mathrm{E}}
$$

In which:

$\mathrm{T}_{\mathrm{U}}=$ useful time available for the operation, $\mathrm{h}$;

$\mathrm{N}_{\mathrm{O}}=$ total number of operational days;

$\mathrm{N}_{\mathrm{I}}=$ number of Sundays and holidays plus inappropriate days;

$\mathrm{W}_{\mathrm{P}}=$ working period, $\mathrm{h}$; and

$\mathrm{M}_{\mathrm{E}}=$ managerial efficiency, decimal.

The average managerial efficiency was estimated as per ASAE D230.3, (1983) as cited by Balastreire (2005) and also by Silveira et al. (2006). According to Balastreire (2005), the estimated values may be used as an orientation in relation to possible values to be obtained for several operations. According to the author, the obtained data in nationwide assays are within the obtained and mentioned ranges by ASAE D230.3.

The available useful time for each operation, the field operational rhythm was calculated, the amount of area to be worked by the time unit, so that the operation could be carried out in optimal time.

$$
R_{F O}=\frac{\text { Farmed } \text { area }(\text { ha })}{T_{U}(h)}
$$

In which:

$\mathrm{R}_{\mathrm{FO}}=$ field operational rhythm, ha/h.

The number of tractors per farm holdings was determined by the operational rhythm and the effective operational capacity to characterize the mechanized operations that were carried out in rural farm holdings (properties) in cultivation of the area within effective working time (Mialhe, 1996; Mantovani et al., 1999; Balastreire, 2005; Mato, 2007).

$$
N_{T P}=\frac{R_{C O}}{C_{F O}}
$$

In which:

$\mathrm{N}_{\mathrm{TP}}=$ number of tractors per farm holdings, units

The area farmed by tractor (ha/tractor) was determined through an analysis of all cultivated areas of the farm holdings and the number of tractors utilized in these areas (Ereno, 2008).

$$
\text { Area farmed by tractor }=\frac{\sum_{i=1}^{n}(\text { useful farmed area })_{\mathrm{i}}}{\sum_{i=1}^{n}\left(\text { tractor }_{\mathrm{i}}\right.}
$$

To calculate the mechanized hourly cost, the structure of the operational cost of production utilized by Instituto de Economia Agrícola (IEA), proposed by Matsunaga et al. (1976), was used. It verifies the necessary time for the 
machinery and the labor force to perform each operation and then defines the technical coefficients in hour/machine. The average prices were collected in the region in Real (R\$), referring to 2011.

The sum of all these expenses resulted into the machine cost in the mechanized operations, for each tractor of the property was computed separately. To obtain the machine total cost, Equation 8 was utilized.

$$
C_{\mathrm{TM}}=\sum_{\mathrm{i}=1}^{\mathrm{n}}(\text { machinecost })_{\mathrm{i}}
$$

In which:

$\mathrm{C}_{\mathrm{TM}}=$ total cost of the machine, $\mathrm{R} \$ / \mathrm{h}$.

From the total machine cost, the field operational cost per hectare was calculated as, Equation 9.

In which:

$$
\mathrm{C}_{\mathrm{FO}}=\frac{\mathrm{C}_{\mathrm{TM}}}{\mathrm{C}_{\mathrm{EO}}}
$$

$\mathrm{C}_{\mathrm{FO}}=$ field operational cost, $\mathrm{R} \$$ ha.

The farm holdings were divided into strata according to their total area because a preliminary data analysis revealed the variation of their sizes. The order of the technical visits to the rural farm holdings for field study was done through raffle (Fonseca \& Martins, 2009).

The results were evaluated by analysis of variance (ANOVA) followed by Kruskal Wallis' test to compare the average at 5\% significance. Dunn's multiple comparisons were utilized with GraphPad Prism Software, version 4.0 for Windows, Graphpad Software (San Diego, CA, USA).

According to Bisquerra et al. (2004), Kruskal Wallis' test can be used to decide if $\mathrm{k}$ independent samples come from different populations, that is, to prove if there are differences among their averages.

\section{Results and Discussion}

Only 149 out of 1,024 rural farm holdings in the municipality of Dracena have tractors out which 117 contributed to this study, making all necessary data available for the project development. The other 32 properties did not collaborate to the study and were not considered because 15 did not allow access and did not make the necessary information available, and 17 did not have wheel tractors.

In Table 1, the total number of rural farm holdings of the municipality of Dracena is presented, as per area strata with or without wheel tractors.

\begin{tabular}{|c|c|c|c|c|c|}
\hline \multirow{3}{*}{$\begin{array}{l}\text { Area strata (ha) } \\
0+5\end{array}$} & \multicolumn{4}{|c|}{ Number and percentage of farm holdings } & \multirow{3}{*}{$\begin{array}{c}\begin{array}{c}\text { Total number of } \\
\text { farm holdings }\end{array} \\
315\end{array}$} \\
\hline & \multicolumn{2}{|c|}{ Without tractor } & \multicolumn{2}{|c|}{ With tractor } & \\
\hline & 310 & $30.3 \%$ & 5 & $0.5 \%$ & \\
\hline 5 ト 10 & 203 & $19.8 \%$ & 11 & $1.1 \%$ & 214 \\
\hline $10 \vdash 20$ & 161 & $15.7 \%$ & 39 & $3.8 \%$ & 200 \\
\hline $20 \vdash 50$ & 109 & $10.6 \%$ & 34 & $3.3 \%$ & 143 \\
\hline $50 \vdash 100$ & 49 & $4.8 \%$ & 20 & $1.9 \%$ & 69 \\
\hline $100 \vdash 200$ & 23 & $2.2 \%$ & 15 & $1.5 \%$ & 38 \\
\hline $200 \vdash 500$ & 16 & $1.6 \%$ & 16 & $1.6 \%$ & 32 \\
\hline $500 \vdash 5000$ & 4 & $0.4 \%$ & 9 & $0.9 \%$ & 13 \\
\hline Total & 875 & $85.4 \%$ & 149 & $14.6 \%$ & 1024 \\
\hline
\end{tabular}

Table 1. Distribution of wheel tractors in rural farm holdings as per area strata

Source: CATI (2008).

It is observed that only $14.6 \%$ of the 1,024 rural farm holdings have wheel tractors. Another important factor was the concentration of wheel tractors in farm holdings with area stratum ranging from 0 to 500 ha. Only 9 farm holdings ( $0.9 \%$ of the total farm holdings in the municipality) have tractors in area stratum above 500 ha, totalizing $6.04 \%$ of the rural farm holdings with wheel tractors. 
Table 2 presents the total number of farm holdings interviewed, the total area and the total area cultivated by tractors.

Table 2. Number of rural farm holdings with wheel tractors and average and total areas of property strata

\begin{tabular}{|c|c|c|c|c|c|c|c|c|}
\hline \multirow{3}{*}{ Area strata (ha) } & \multirow{3}{*}{$\begin{array}{l}\text { Total No. of } \\
\text { properties }\end{array}$} & \multicolumn{7}{|c|}{ Interviewed rural properties per stratum } \\
\hline & & \multirow{2}{*}{ No. } & \multirow{2}{*}{$(\%)$} & \multicolumn{2}{|c|}{ Area per stratum (ha) } & \multicolumn{2}{|c|}{ Useful farmed area (ha) } & \multirow{2}{*}{$(\%)$} \\
\hline & & & & Total & Average & Total & Average & \\
\hline 0 - 15 & 33 & 23 & 69.7 & 220.28 & 9.58 & 174.82 & 7,60 & 79,4 \\
\hline $15 \vdash 30$ & 35 & 31 & 88.6 & 633.64 & 20.44 & 550.34 & 17,75 & 86,9 \\
\hline $30+60$ & 26 & 21 & 80.8 & 868.78 & 43.44 & 824.16 & 41,20 & 94,9 \\
\hline 60 - 200 & 30 & 24 & 80.0 & 2624.90 & 109.37 & 2371.91 & 101,3 & 90,4 \\
\hline $200 \vdash 1800$ & 25 & 18 & 72.0 & 9894.42 & 549.69 & 8226.06 & 457,00 & 83,1 \\
\hline Total & 149 & 117 & 78.5 & 14242.02 & & 12147.29 & & 85.3 \\
\hline
\end{tabular}

Figure 1 reveals that $81.1 \%$ of the tractors are concentrated in the range of 0 to 200 ha, corresponding to a total area of $4,347.60$ ha or $30.5 \%$ of stratum areas. The properties that are bigger than 200 ha, totalizing an area of $9,894.42$ ha $(69.5 \%$ of strata), have only $18.9 \%$ of tractors. According to Gimenez and Milan (2007), the size of the rural farm holdings influences the amount of available mechanized resources per area. The amount of machinery was smaller with the increase of farm holdings areas.

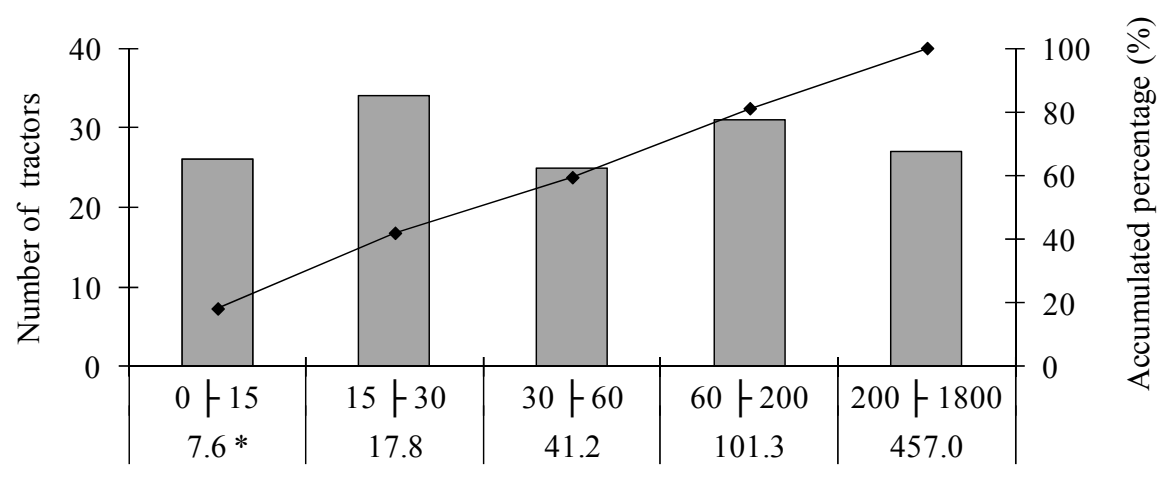

Rural property strata (ha)

* Average farmed area by stratum(ha)

$\square$ Number of tractors $\rightarrow$ Accumulated percentage

Figure 1. Distribution of wheel tractors as per rural farm holdings strata

The number of tractors per stratum was $24.19 \%$ greater than the number of properties. The average in the 0 to 15 stratum was 1.13 tractors per property, whereas, in the 200 to 1,800 stratum, it was 1.5 tractors per property, an increment of $32.74 \%$; however, the increase in the number of tractors per stratum was lower compared to the increase of farmed area $(4,605.45 \%)$.

The human resources in 117 properties were characterized by the utilization of hired workforce (registered worker), family workforce, and temporary workforce that correspond to 45.12, 32.21, and 22.67\%, respectively, with a total of 271 people.

It was observed that the hired workforce presented higher values in strata over 60 ha, while the family workforce reduces this value to zero in the same strata. In small properties, the family workforce was a part of the hired workforce. The temporary workforce presented higher indexes where the family workforce had smaller values, and it was more required during greater intensity periods of the production system. 
The use of workforce concentrated in smaller strata where $71.59 \%$ of the workers are in properties that are up to 100 ha, resulting in a smaller area per person (Figure 2). This concentration can be explained by observations done in the interviews in which the smaller properties presented a greater number of small manual activities, mainly with the cleaning and maintenance of animal shelters and machinery and domestic services in general, like gardening.

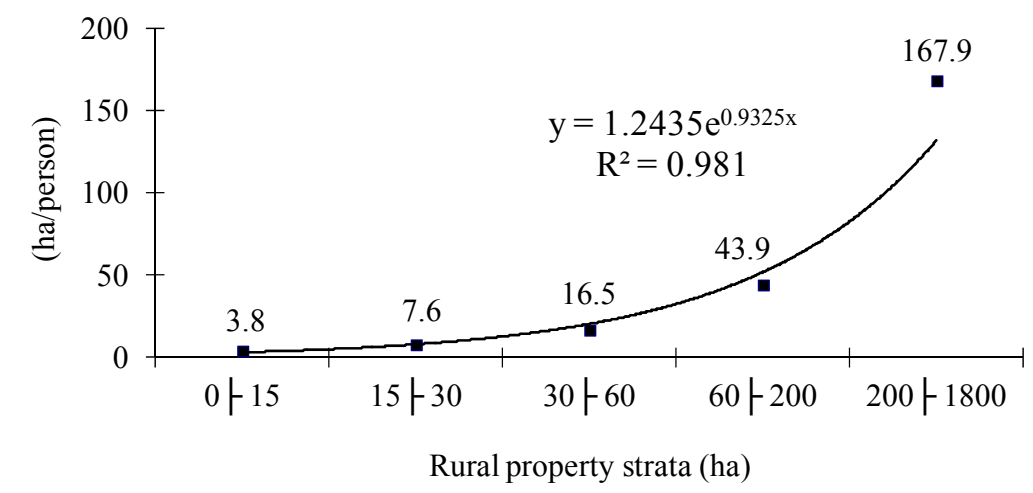

- Useful farmed area per person (ha/person) —Expon (Useful farmed area per person (ha/person))

Figure 2. Useful farmed area per person in cultivated strata

It was observed that the agricultural equipment like disk plow and leveling harrows respectively correspond to 24.4 and $22.6 \%$, of the total input equipment, but in 117 visited properties, the values were 81.2 and $75.2 \%$, respectively. These values occur mainly because of the soil management using the conventional system (plowing and harrowing) that is predominant in this region.

The main agricultural activities in 117 farm holdings were sugarcane and grazing with 42.7 and $65 \%$, respectively. However, the values were 25.6 and $16.8 \%$, respectively, when all activities in the farm holdings are evaluated. These values are mainly related to the animal husbandry system for beef and milk cattle that corresponds to $34.4 \%$ of the activities altogether and are present in $87.2 \%$ of farm holdings.

In Figure 3, the average time of manufacturing and average liquid output of tractors in function of manufacturer is presented.

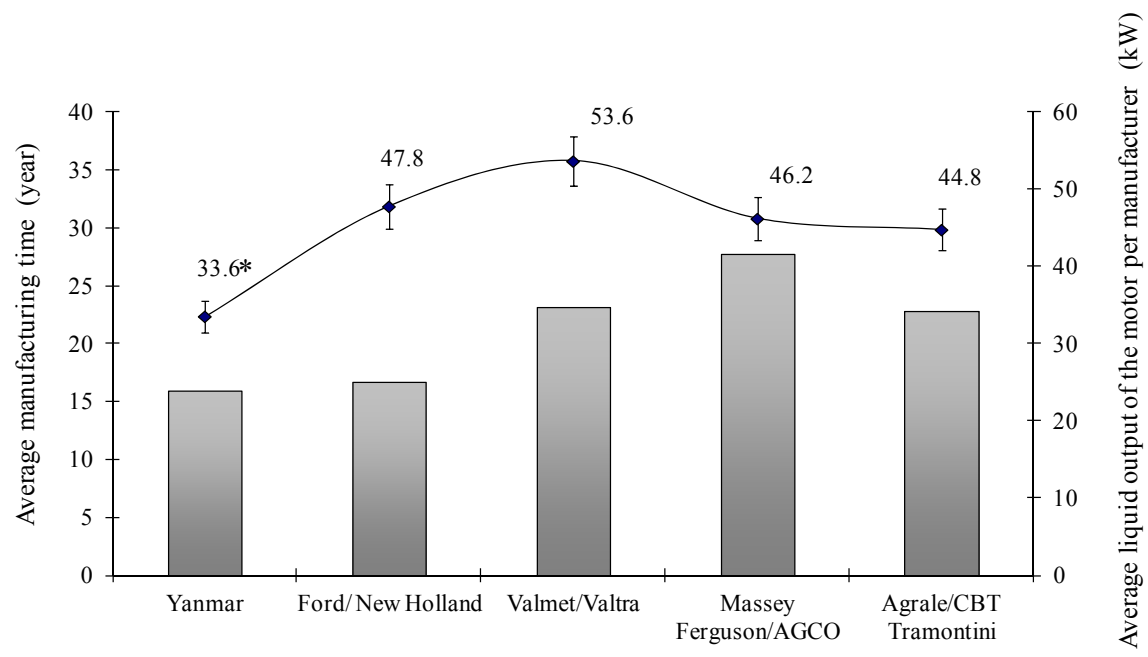

$$
\square \text { Average manufacturing time (year) } \rightarrow \text { Average liquid output of the motor per manufacturer }(\mathrm{kW})
$$

Figure 3. Average manufacturing time and average liquid output of motors in function of manufacturer. *result presented in the curve of average liquid output of the motor of "Yanmar" manufacturer differs significantly from the others by Kruscal Wallis' test $(\mathrm{P}<0.05)$ 
It is verified that New Holland tractors, the second favorite one with $15.4 \%$ in the visited strata, presents an inferior difference of the average manufacturing time, around 11 years, when compared to the first one with $66.4 \%$. In the visited strata, the presence of 20 -year-old tractors was $36.4 \%$.

The average life of the tractors in the studied strata was found 21.7 years. This shows that most of the tractors are obsolete, that their operational efficiencies are compromised, and that there is a need to replace these tractors (this machinery).

The average horse power of the tractors being used in the strata was $45.2 \mathrm{~kW}$, and the difference from the highest power output and the lowest one is 25\%. The manufacturers of "Yanmar" models that presented the lowest output and significantly differed from the other manufacturers was concentrated in the smaller strata, totalizing an average useful area of 7.14 hectares per tractor.

Table 3 shows the drawbar horse power of the tractor $(\mathrm{kW})$, the area farmed by the tractor (ha/tractor) and the mechanization index $(\mathrm{kW} / \mathrm{ha})$ in cultivation of the strata.

Table 3. Average values of life, brake horse power of the tractor, area farmed by tractors and mechanization index in cultivation of the area strata.

\begin{tabular}{ccccc}
\hline Area strata (ha) & $\begin{array}{c}\text { Life of the tractor } \\
\text { (year) }\end{array}$ & $\begin{array}{c}\text { Drawbar power of } \\
\text { tractor }(\mathrm{kW})\end{array}$ & $\begin{array}{c}\text { Area farmed by } \\
\text { tractor (ha/tractor) }\end{array}$ & $\begin{array}{c}\text { Mechanization } \\
\text { index (kW/ha) }\end{array}$ \\
\hline $0+15$ & $31.04 \mathrm{a}$ & $45.81 \mathrm{a}$ & $7.21 \mathrm{a}$ & $7.38 \mathrm{a}$ \\
$15+30$ & $28.56 \mathrm{ab}$ & $45.84 \mathrm{a}$ & $17.34 \mathrm{~b}$ & $2.76 \mathrm{ab}$ \\
$30+60$ & $24.44 \mathrm{ab}$ & $57.85 \mathrm{ab}$ & $35.18 \mathrm{bc}$ & $1.52 \mathrm{bc}$ \\
$60+200$ & $18.90 \mathrm{~b}$ & $62.70 \mathrm{ab}$ & $87.88 \mathrm{~cd}$ & $0.79 \mathrm{~cd}$ \\
$200+1800$ & $22.15 \mathrm{ab}$ & $79.58 \mathrm{~b}$ & $371.90 \mathrm{~d}$ & $0.22 \mathrm{~d}$ \\
\hline
\end{tabular}

Average followed by distinct letters in the column differ among themselves by Kruscal Wallis' test $(\mathrm{P}<0.05)$.

The total average output of the tractor was $58.36 \mathrm{~kW}$ and the difference between the highest and lowest output between the strata of 0 to 15 and 200 to 1800 ha was $73.28 \%$.

Figure 4 shows the average manufacturing time and the average liquid output of tractors in function of strata. It is observed that the liquid output of the motor presented an increasing linear behavior in function of the increase of stratum areas. However, the manufacturing time of tractors presented an inverse behavior to liquid output by decreasing $40.1 \%$ as strata increased, as seen in Table 3.

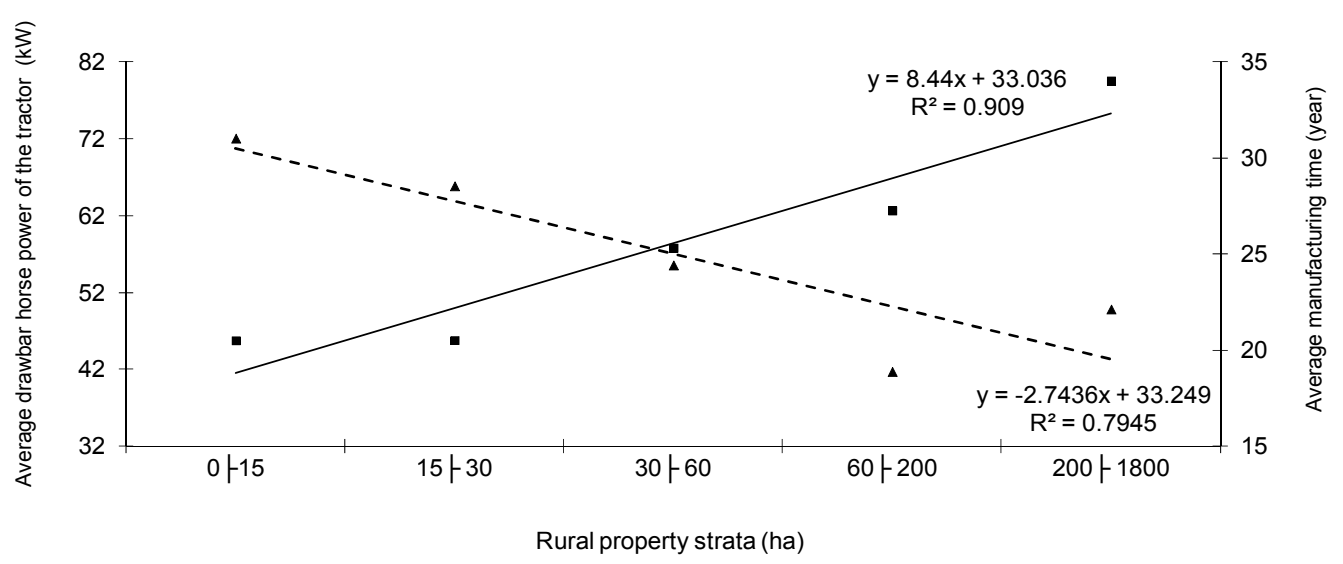

$$
\begin{aligned}
& \text { - Average drawbar horse power of the tractor per stratum }(\mathrm{kW}) \quad \Delta \text { Average manufacturing time of tractors (year) } \\
& \text { - Linear (Average drawbar horse power of the tractor per stratum }(\mathrm{kW})) \quad \text { - - Linear (Average manufacturing time of tractors (year)) }
\end{aligned}
$$

Figure 4. Average life (manufacturing time) and average drawbar horse power of tractors used in strata 
The presence of tractors that were newer than 10 years in the interviewed strata was $21.68 \%$, whereas it was 14.68 , 23.08 and $40.56 \%$ for the tractors that were 11 to 20 years old, 21 and 30 years old and over 31 years old, respectively, totalizing $78.32 \%$ of tractors. The total average time between the strata was 25 years; this shows that most tractors are obsolete, that their operational efficiencies are compromised, and that there is the need to replace this machinery. One fundamental aspect to determine production cost is depreciation which is related to the loss of productive efficiency of the agricultural machine due to wearing out through use, representing a real cost to the proprietor and it is observed as a linear function of the machine age, varying uniformly throughout its useful life (Companhia Nacional de Abastecimento - CONAB, 2010).

Figure 5 shows the mechanization index and the useful area farmed by a tractor in function of the strata.

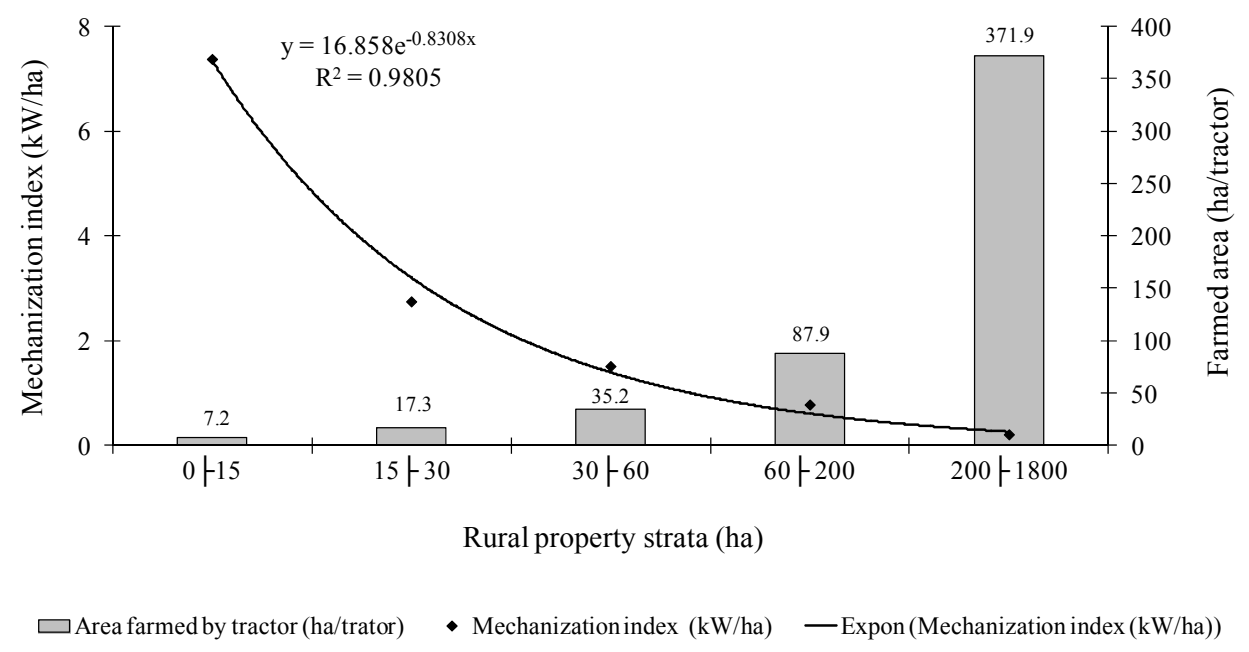

Figure 5. Useful area farmed by tractor and mechanization index in function of strata

It is observed that the critical situation occurs in the area stratum of 200 to 1,800 ha where the area farmed by tractor was 371.9 ha/tractor, $117.87 \%$ higher than the Brazilian average of 170.7 ha/tractor (Associação Nacional dos Fabricantes de Veículos Automotores - ANFAVEA, 2007). When compared to the average in other countries like Argentina, Canada, the United States, France and the United Kingdom, the results are 93.1, 62.3, 36.4, 14.6 and $11.3 \mathrm{ha} /$ tractor, respectively, except for the stratum of 200 to $1,800 \mathrm{ha}$, all the other values are close or lower than those countries. The general average of the area farmed by tractor was 103.9 ha/tractor,

$64.3 \%$ lower than the national average and $104.5 \%$ higher than the world average of 50.8 ha/tractor (ANFAVEA, 2007).

It is observed that the average of the mechanization index was $2.53 \mathrm{~kW} / \mathrm{ha}$, ranging from 0.22 to $7.38 \mathrm{~kW} / \mathrm{ha}$, between the largest stratum and the smallest one, and the percentage difference between these strata was $3,254.55 \%$. It is observed that the increase in drawbar horse power of tractors between the smallest and largest strata was $73.28 \%$, and the increase of the useful farmed area in these same strata was $4,605.45 \%$. This great difference between the percentage increase was predominant for the reduction of the mechanization index, that is, the mechanization index per stratum reduced whereas the area increased. This reduction was also influenced by the concentration of tractors in the small areas of the strata.

Schlosser et al. (2004) analyzed 87 farm holdings and determined the mechanization index that ranged from 1.96 and $7.82 \mathrm{~kW} / \mathrm{ha}$, which was smaller for the properties with greater agricultural area. The higher output availability was in smaller area properties, showing worse investment distribution, but allowing greater effective operational capacity. This difference in the mechanization index among strata shows that some properties present a number of tractors above the area necessities or supersized machinery; likewise, some properties present undersized machinery (Edwards \& Willians, 2001).

The total machinery cost $(\mathrm{R} \$ / \mathrm{h})$, effective operational capacity $(\mathrm{ha} / \mathrm{h})$ and the field operational cost $(\mathrm{R} \$ / \mathrm{ha})$ in cultivated strata are shown in Table 4. 
Table 4. Average values of total machinery cost and field operational cost through effective operational capacity

\begin{tabular}{cccc}
\hline Area strata (ha) & $\begin{array}{c}\text { Total machinery cost } \\
(\mathrm{R} \$ \mathrm{~h})\end{array}$ & $\begin{array}{c}\text { Effective operational } \\
\text { capacity (ha/h) }\end{array}$ & $\begin{array}{c}\text { Field operational cost } \\
(\mathrm{R} \$ / \mathrm{ha})\end{array}$ \\
\hline $0+15$ & $24.27 \mathrm{a}$ & $0.60 \mathrm{a}$ & $40.31 \mathrm{ab}$ \\
$15+30$ & $27.02 \mathrm{ab}$ & $0.74 \mathrm{ab}$ & $36.25 \mathrm{ab}$ \\
$30+60$ & $29.65 \mathrm{ab}$ & $0.58 \mathrm{a}$ & $50.95 \mathrm{ab}$ \\
$60+200$ & $29.36 \mathrm{ab}$ & $0.51 \mathrm{a}$ & $58.10 \mathrm{a}$ \\
$200+1800$ & $35.50 \mathrm{~b}$ & $1.51 \mathrm{~b}$ & $23.46 \mathrm{~b}$ \\
\hline
\end{tabular}

Averages followed by distinct letter in the column differ among themselves by Kruscal Wallis' test $(\mathrm{P}<0.05)$.

The field operational cost ( $\mathrm{R} \$ \mathrm{ha})$, total machinery cost $(\mathrm{R} \$ \mathrm{~h})$ and effective operational capacity $(\mathrm{ha} / \mathrm{h})$ of the machinery in function of the stratum are presented in Figure 6.

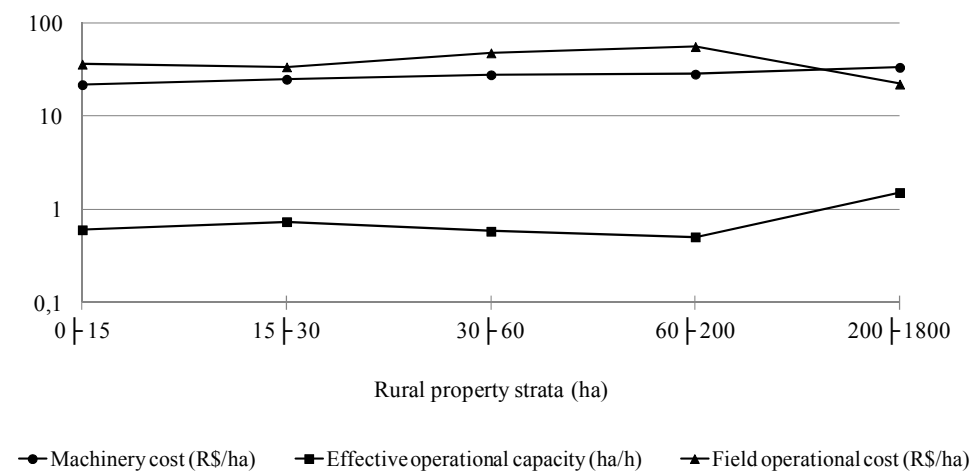

Figure 6. Distribution of the field operational cost and machinery cost in functionof the effective operational capacity in strata

The effective operational capacity (ha/h), field operational rhythm (ha/h) and the number of tractors in function of working days for the producers of the municipality are shown in Figure 7.
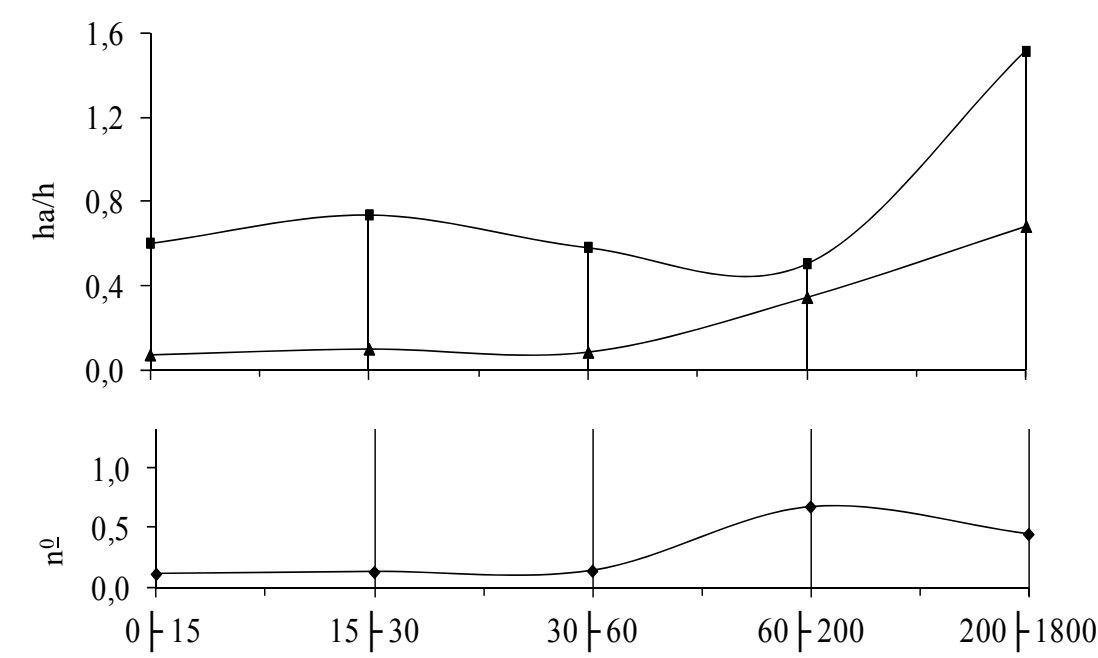

Rural property strata (ha)

$\rightarrow$ Effective operational capacity $(\mathrm{ha} / \mathrm{h}) \rightarrow$ Number of tractors $\rightarrow$ Field operational rhythm $(\mathrm{ha} / \mathrm{h})$

Figure 7. Determination of effective operational capacity, field operational rhythm and number of tractors in function of rural property strata 
The average of the available working days was 18 days a month. According to the information collected in the interviews, to obtain the average value, Saturdays were not accounted for, and Mondays through Fridays were the working days for the operational activities of mechanization.

On an average 1,000 worked hours/year were considered to obtain the working hours, according to Anuário da Agricultura Brasileira - AGRIANUAL (2010), and then divided by 12 months and sequentially by the available working days in a month, resulting in 4.6 hours/day of average working hours. Considering the managerial efficiency for each mechanized operation, the average available working time for the operations in the rural properties was 3.56 hours a day (Balastreire, 2005; Silveira et al., 2006). Thus, the average available total time for the operations was 769.7 hours a year, which is $23.03 \%$ lower than the national average of 1,000 hours a year of tractor operations (AGRIANUAL, 2010).

The average operational rhythm was $0.26 \mathrm{ha} / \mathrm{h}$ (ha) in relation to the average effective operational capacity of $0.79 \mathrm{ha} / \mathrm{h}$, observing an average difference of $203.85 \%$. This shows that most producers are not utilizing the machinery rationally, concentrating mechanized operations on few days a year so that the utilized time for the activities is much lower than the available time for the same operations to be carried out. In Figure 7, it is also shown that some properties present the number of tractors in function of working days above the area necessities, that is, supersized machines (Edwards \& Willians, 2001). Karimi et al. (2008) verified that inadequate activities within the agricultural standards influenced the non-utilization of tractors in the long run. The authors suggest that each property carry out appropriate activities within the agricultural standards so that the operations in which tractors are needed be perfectly distributed throughout the year.

\section{Conclusions}

Based on the results of this study, it can be concluded that:

The average area farmed by tractors was lower than the national average and that the depreciation state of the tractors was cumulative; therefore, their average life (manufacturing time) was higher than 10 years, influencing the operational efficiency of the tractors in the properties and demanding the replacement of this machinery

The agricultural activities practiced in the rural farm holdings were inefficient due to the small useful worked areas and limited farm operations. This resulted in higher variation of the mechanization index, showing a great contrast in the technical rationality of mechanized operations in the properties of the municipality.

The field operational cost could be minimized with the increase of the effective operational capacity for all rural property strata.

In summary, the field operational rhythm and the number of tractors in the properties showed that the agricultural activities in these rural properties should be planned rationally, utilizing all machinery and equipment, through cooperatives and associations, attending several properties efficiently for resource utilization - with reduction of the operational cost - and obtained productivity.

\section{Aknowledgements}

We thank Fundação de Amparo à Pesquisa do Estado de São Paulo (FAPESP) for the financial support (Process Number 2009/07194-0) and for the Scientific Initiation scholarship (Process Number 2009/15613-2), Pró-Reitoria de Pesquisa (PROPe) and Fundação para o Desenvolvimento da Unesp (FUNDUNESP), and CATI/Regional of Dracena for the contribution to carry out the study.

\section{References}

Agrianual. (2010). Anuário da Agricultura Brasileira. São Paulo: Agra FNP Pesquisas Ltda.

Andrade, P., \& Jenkins, B. (2003). Identification of Patterns of Farm Equipment Utilization in Two Agricultural Regions of Central and Northern Mexico. Agricultural Engineering International: the CIGR Journal of Scientific Research and Development. Invited Overview Paper. Vol. (V). June.

American Society of Agricultural Engineers - ASAE D497.2. (1999). Agricultural machinery management data (pp. 332-339). St. Joseph, MI.

American Society of Agricultural Engineers - ASAE. D497.4. (2003). Agricultural machinery management data. In: Standards 2003 (pp. 373-380). St. Joseph, MI.

Associação Nacional dos Fabricantes de Veículos Automotores - ANFAVEA. (2010). Anuário da Indústria $\begin{array}{llll}\text { Automobilística } & \text { Brasileira, } & 2007 . & \text { Retrieved }\end{array}$ http://www.anfavea.com.br/anuario2007/Cap1_15_2007.pdf

Balastreire, L. A. (2005). Máquinas agrícolas. Piracicaba, SP: Câmara Brasileira do Livro, SP, Brasil. 
Bisquerra, R., Sarriera, J. C., \& Martínez, F. (2004.). Introdução à estatística: enfoque informático com o pacote estatístico SPSS. Tradução: Fátima Murad. Porto Alegre: Artmed Editora.

Companhia Nacional de Abastecimento - CONAB. (2010). Custos de produção agrícola: a metodologia da Conab. Brasília: Conab.

Coordenadoria de Assistência Técnica Integral - CATI. (2008). Instituto de Economia Agrícola. Levantamento censitário de unidades de produção agrícola do Estado de São Paulo - LUPA 2007/2008. São Paulo: SAA/CATI/IEA, 2008. Retrieved from http://www.cati.sp.gov.br/projetolupa

Edwards, W., \& Willians, D. (2011). Machinery management: farm machinery selection. Iowa State University of Science and Technology, Ames, Iowa. November 2001. Retrieved from http://www.extension.iastate.edu/Publications/PM952.pdf

Ereno, L. H. Z. (2008). Estudo comparativo entre a utilização real e a determinada pelo planejamento da mecanização agrícola em empresas rurais de soja e arroz. Dissertação (Mestrado em Engenharia Agrícola). Universidade Federal de Santa Maria, Centro de Ciências Rurais. Santa Maria/RS.

Federação da Agricultura e Pecuária do Estado de Mato Grosso - FAMATO. (2011). Diagnóstico da Cadeia Produtiva Agroindustrial da Bovinocultura de Corte do Estado de Mato Grosso - Cuiabá, outubro de 2007. Retrieved http://www.famato.org.br/arquivos/PEC\%20MT\%20DIAGNOSTICO\%20COMPLETO\%2022-11-07.pdf

Fonseca, J. S., \& Martins, G. A. (2009). Curso de estatística. São Paulo. Atlas.

Gimenez, L. M., \& Milan, M. (2007). Diagnóstico da mecanização em uma região produtora de grãos. Engenharia Agrícola. Jan./Abr., 27(1), 210-219. http://dx.doi.org/10.1590/S0100-69162007000100015

Karimi, M., Rafiee, S., Pour, A. R., Khairalipour, K., \& Shahin, S. (2008). A Pattern to Distribute Tractor Power from the Viewpoint of Energy Case Study: Isfahan Province in Central Region of Iran. American-Eurasian. J. Agric. \& Environ. Sci., 3(4), 526-531.

Lotte, R. I. (2005). A atuação do Secretário Executivo no Oeste do Paraná numa economia baseada no agronegócio. Revista Expectativa, Toledo, 4, 57-64.

Mantovani, E. C., Leplatois, M., \& Inamassu, R. Y. (1999). Automação do processo de avaliação de desempenho de tratores e implementos em campo. Pesquisa Agropecuária Brasileira. Julho, 34(7), 1241-1246.

Mato, M. A. (2007). Modelo para planejamento operacional e econômico de sistemas mecanizados com a consideração da pontualidade. 2007. (Mestrado em Agronomia). Escola Superior de Agricultura Luiz de Queiroz - ESALQ/USP. Piracicaba/SP. 88p.

Matsunaga, M., Bemelmans, P. F., Toledo, P. E. N., Dulley, R. D., Okawa, H., \& Pedroso, I. A. (1976). Metodologia de custo de produção utilizada pelo IEA. Agricultura em São Paulo, São Paulo, 23(1), 123-139.

Mialhe, L. G. (1996). Máquina agrícola: ensaios \& certificação. Piracicaba, SP. Fundação de Estudos Agrários Luiz de Queiroz.

Olaoye, J. O., \& Rotimi, A. O. (2010). Measurement of Agricultural Mechanization Index and Analysis of Agricultural Productivity of some Farm Settlements in South West, Nigeria. Agricultural Engineering International: the CIGR Ejournal. Manuscript 1372. Vol XII, January.

Rodrigues, A. S., Guerreiro, E., Miranda, G. M., \& Milleo, R. D. S. (1997). Enfoque Sistêmico em P \& D - A Experiência Metodológica do IAPAR - Caracterização e Tipologia de Sistemas de Produção. Circular IAPAR no. 97. Londrina: IAPAR.

Samavatean, N., Rafiee, S., \& Mobli, H. (2011). An Analysis of Energy Use and Estimation of a Mechanization Index of Garlic Production in Iran. Journal of Agricultural Science, 3(2), 198-205. http://dx.doi.org/10.5539/jas.v3n2p198

Schlosser, J. F., Machado, O. D. C., Debiasi, H., \& Pinheiros, E. D. (2004). Índice de mecanização de propriedades orizícolas no Rio Grande do Sul, Brasil. Ciência Rural, Santa Maria, 34(3), 791-794.

Silveira, G. M., Yanai, K., \& Kurachi, S. A. H. (2006). Determinação da eficiência de campo de conjuntos de máquinas convencionais de preparo do solo, semeadura e cultivo. Campina Grande/PB. Revista Brasileira de Engenharia Agrícola e Ambiental. DEAg/UFGG. Mar., 10(1), 220-224. 
Vilagra, J. M. (2009). Adequação ergonômica de trator agrícola de média potência: Construção e validação de um instrumento de avaliação a partir do construto de conforto, segurança e eficiência. 2009. $133 \mathrm{f}$. Tese (Doutorado) - Universidade Federal De Santa Catarina, Florianópolis.

\section{Copyrights}

Copyright for this article is retained by the author(s), with first publication rights granted to the journal.

This is an open-access article distributed under the terms and conditions of the Creative Commons Attribution license (http://creativecommons.org/licenses/by/3.0/). 